\title{
THE LIMITATIONS OF CREATIVE THINKING IN THE NIGERIAN EDUCATIONAL SYSTEM
}

\author{
by
}

\author{
Dr. Musa Suleiman \\ Faculty of Education, \\ University of Sokoto, Nigeria.
}

\begin{abstract}
The educational system in Nigeria today puts too much emphasis on'blind obedience to the teacher in the classroorn, conformity to the age old established norms and practices in the school and reproduction of ideas in the examination. This is the legacy of the inherited colonial education which aims were geared towards producing white collar jobs that would sustain the colonial administration. It has been argued that this system is not favourable to the generation of new ideas and full realisation of human creative potential. Various research studies on creativity and its measurement have been reviewed. It has been generally noted that creative thinking cannot be fostered in a system of education that puts too much premium on an examination. Some recommendations for the development of creative thinking in our schools (such as putting emphasis on productive rather than reproductive thinking, having a more relaxed atmosphere that allows students to toy freely with objects) are made.
\end{abstract}

\section{Introduction:}

It is a well known fact that the system of education currently in vogue in Nigeria today derived its root from the missionaries and later, the colonial government. The main objectives of the missionary education were essentially to teach the Bible, sing the hymns and communicate orally as well as in writing. As to the colonial government, it had no clear objectives on education until 1925 when it received a report on education in Nigeria compiled by an American Philanthropist organisation known as Phelps-stokes. As reported in Fafunwa (1974) the main highlights of the report were:-

(1) The record of colonial government in Africa was a mixture of good and bad.

(2) Although educational facilities were largely credited to the missionaries, many of them did not realise the relevance of education in the development of the people.

(3) Many of the problems of education were due to failure to adapt school work to African conditions, "and school methods which have been discarded in American and Europe were still in vogue in Africa". 
The colonial government was influenced by this report in issuing an educational policy in 1925 with emphasis on improving the quality of education. Improving quality here means better supervision of teachers and establishment of advisory boards to supervise these policies. The main goal of establishing schools in the colonial era was to produce clerks and other supporting staff to maintain the colonial administration. These schools were not meant to produce men of ideas and critical thinking to solve the problems of Nigeria.

The present educational system in Nigeria remains essentially along the lines of the colonial administration in curriculum content and structure. During the colonial era, the grammar schools with their emphasis on English and Latin were the citadels of intellectualism. The products of these institutions were supposed to be the cream of the society who should have nothing to do with manual labour. This attitúde still continues today in our schools and colleges. The average mentality of a Nigerian school student, as in the past is elitist and shuns anything local in favour of the more sophisticated European standards. This was perhaps the thinking behind Fafunwa's (1974) observation "that the high school boy or girl in Africa must learn that no job is beneath his or her " dignity, indeed Africa can never hope to rise from its present economic abyss if it has an army of white-collar workers who consider themselves of first importance merely because they have completed a secondary education".

There are some key areas in the system of education that have some implications on creative thinking.

\section{Emphasis on Reproduction of Ideas}

In a study on attitudes of Integrated Science Teachers Toward Assessment Practices, Okpala and Onocha (1973) reported that 40.5 percent of teachers in their investigation disagreed with allowing students to assess their own science progress, while only.9.5 percent agreed. The underlying implication of this attitude is that only teachers should judge student's progress and in a system of education like ours this would mean measuring students ability to reproduce what they were taught. This is in confirmity with the objectives of schooling in Nigeria - that students should reproduce what they were taught rather than be productive in their thinking. A good student is therefore one who can pay rapt attention to the teacher in the class, absorb the facts that are poured in his 'empty' mind and reproduce them again when they are called for. 


\title{
2. Emphasis on Conformity
}

Nduka (1975) observed that there will little emphasis on telling students to 'find out things for themselves when they were being daily fed with facts and dogmas". This may partly explain why there is general lack of initiative from our school graduates. This is a reflection of the wider society in which young children are seen rather than heard. As observed by Fafunwa (1974) an average African child

\footnotetext{
"between the age of 3 and 6 is in a disadvantaged situation compared with his European counterpart. He usually asks what and where between 3 and 4 and by 5 he wants to know the how and why of things. His vocabulary grows and so does his experience in terms of objects around him. Studies in child development have demonstrated that the extent to which he will continue to ask questions will depend on the cultural experiences". (Fafunwa, 1974).
}

However, the average African parent

\begin{abstract}
"believes that the child is to be seen and not heard - an outmoded concept. This approach naturally stifles the childs curiosity and impedes the development of his reasoning powers. Most parents, particularly those who are illiterate, consider a three to six year old's questions as sheer impertinence; many even regard them as bad manners, which should of course be nipped in the bud by hitting the child". (Fafunwa, 1974).
\end{abstract}

Under these circumstances, the child is likely to extend his tentacles to the school teachers to satisfy his curriosity. Alas, the teacher either, through poor training and insecurity, is likely to frown at questioning in his classroom. Opara (1984) observed that:

"Quite often, because of the didactive nature of our education, there is a repression of the natural urge in children to ask questions".

Similarly Ferron (1965, in Opara 1984) noted that:

"discouraging children from asking questions and exploring their environment (in West African Schools) is one of the factors depressing African childrens' scores in educational tests". (Ferron, 1965).

\section{Examination and the Curriculum:}

Leading educationists in Nigeria unanimously agree that one of the most disquieting features of our educational system from top to bottom is the preoccupation with examination (Nduka, 1975; Fafunwa, 1974). It is even wondered whether one can call the educational system, a system of education or a system of examinations. It is reasonable to understand this phenomenon from the historical demand for salaried workers. If there is some reasoning behind this trend, it becomes unreasonable to expect the system to encourage originality and productive thinking. One cannot hope to harvest wheat from the seeds of millet. If Nigeria is in need of creative men in the sciences and the arts in order 
to solve its multifarious problems, some serious re-examination of the educational system is called for. At the moment the success of education in Nigeria is judged strictly by one's performance in examinations. Fafunwa (1974) puts it more succinctly thus:

\footnotetext{
"if, education is the aggregate of all the processess by which a person develops skills, abilities, attitudes and other forms of behaviour of positive and meaningful value in the society in which he lives; if it is a system based on certain philosophical or theoretical assumptions and seeks to justify its usefulness in terms of its practices and results, then most of the educational systems in Africa can hardly stand the test"'. (Fafunwa, 1974: 194)
}

Our survival as a people depends on the quality of creative men and women we can produce in the next generation. Instead of being concerned about the facts our students cram in the classroom, we should enquire how resourceful they are and how flexible are their thoughts.

\section{The Teaching Method:}

The peculiar circumstances of our system of education create heavy demands on the teacher to the extent that he is expected to be ever ything in the classroom. He should not only demonstrate unquestionable competeney in his area of specialisation but also become a $\mathbf{M r - K n o w - A l l . ~ B y ~ v i r t u e ~ o f ~ t h e ~}$ authoritarian nature of our system of education, the teacher is always right and he is not to be roundly condemned for that. For, as a teacher, he is conscious of the fact the moment he indicates ignorance even in a discipline outside his own field of specialisation, he might as well be considered incompetent in his own discipline and he may fail to command respect accorded to a teacher. This is the dilemma which tends to compel a teacher to commit a professional misconduct of telling lies in order to survive in the system. This teacher-know-all mentality results in a situation whereby a typical classroom scenery is that of someone in front of a class talking himself to death pouring 'knowledge' into the 'empty' minds of the children. What we need today is a child-centred learning which puts emphasis on creative problem solving in teaching and learning if the children are to apply this attitude in their future life.

\section{Summary}

On the whole it has been argued that our system of education puts too much premium on conformity and examination. Reviewing the literature on creative thinking there is no evidence to suggest a strong association between blind conformity and creative problem solving. It is this aspect that the author intends to highlight in the next section. 


\section{CREATIVITY}

The question of what is creativity, is not easy to answer. To some people it is something of a mysterious nature and therefore is not amenable to measurement and investigation. If this posture is taken then as noted by Shapiro (1968) "we may as well forego any attempt at experimental investigations of creative ability and confine ourselves to armchair speculation"'. He also argued that creative geniuses

\footnotetext{
"have always been few and far between and even that handful alive today and universally recognised as being of the first order of creativity is not liable to congregate as a group of subjects for testing purposes". (Shapiro, 1968)
}

In order to get out of this dilemma, he proposed that since

"the difference between the individual who creates a new type of bicycle tyre and a Darwin who revolutionises the whole of biology is a matter of degree and not kind". (Shapiro, 1968)

we can study large groups and from the findings make some predictions about those few rare creative geniuses. It in this principle of continuity that makes possible the investigation of creativity in people who are not necessarily distinguished.

There are various definitions of creativity which situation is due not essentially to confusion but to its complexity and multi-faced nature. Some definitions (eg Ghiselin, 1963a) were formulated in terms of process. Others (eg Krenter and Krenter 1964) would prefer the term 'creative' to be exclusively reserved for such fields as art, music and writing, while Spearman (1930) prefers a content-free definition in which

\footnotetext{
"the power of the human mind to create new content by transferring relations and thereby generating new correlates - extends its sphere not only to representation of ideas, but also to the fully senscious presentations, and as given in ordinary seeing, hearing, touching and the like, for every one of us". (Spearman, 1930).
}

Torrance (1974) seemed to have accepted this rather general conception of creativity when he defined it as:

\footnotetext{
"a process of becoming sensitive to problems, deficiencies, gaps in knowledge, missing elements, disharmonies and so on: identifying the difficulty, searching for the solutions. making guess or formulating hypothesis about the deficiencies: testing and re-testing these hypotheses and possibly modifying and retesting them; and finally communicating the results".
}

\section{Background to the Studies of Creativity}

In a review on Psychometric Measurement of creativity Razik (1967) indicated that the development of the educational programmes for creativity has 
not been a smooth one. There are some "conceptual blocks" that had to be removed for any meaningful progress to be made. It was conceived (and probably still so in Nigeria) that creativity was a property of the genius and natural and that there is nothing education can do to cultivate it. The development of the Atomic Bomb suggested what man can do in shaping the destiny of humanity. It soon became clear to the United States that the cultivation of human potential cannot be left to the individual and chances alone. Men of creative potential would have to be identified and cultivated for society to reap the fruits of their endeavour.

Subsequently, investigations on the nature and nurture of creativity became a subject of concern for various governments and military establishments in Europe and America.

It is one thing for creativity to be a subject of concern for governments and other establishments, it is another thing for it to be rewarded in the educational establishments. This problem has been raised by Torrance (1975) and Razik (1967). Part of the difficulty lied with providing adequate measurement criteria with concrete specification of the behaviours desired and also the means of judging attainment.

It has been widely reported (eg Guilford, 1967 a Getzels and Jacksons, 1962; Torrance, 1962 and Razik et al 1967) that the type of tests used in our schools essentially emphasised intelligence and achievement tests. The former emphasise one's ability to do school work while the latter deal with one's accomplishments at school. They do not incorporate creative abilities. Against this background, those interested in the progress of creative thinking abilities in our schools had to deal with the development of new concepts and measures which the educators would need to guide their efforts.

\section{Research Studies on Creativity}

It seems to be generally agreed among researchers (viz. Torrance, 1962; Razik 1967, and Shapiro 1968) that the dawn of the present studies on creativity was heralded by Guilford (1950).

Especially useful in the study of creativity is Guilford's distinction between divergent and convergent thinking operations. Convergent thinking implies "the narrowing down of possibilities in the production of one possible answer to a problem". Divergent thinking requires the production of as many answers as possible. Guilford (1967) in his Theory of intellect considered divergent thinking as an important factor in creative thinking and is measured by fluency, flexibility, originality and elaboration. 
It has been reported (Pole, 1969) that the tests used most frequently by Guilford and adapted by others were:-

1. Word fluency

2. Consequencies

3. Uses

4. Match problem

5. Plot titles

6. Circule test

7. Word combination

Guilfords' tests were group administered with strict time limits. These tests were adopted by many investigators in the field of creativity.

Among the first to adopt Guilford's tests were Getzels and Jackson (1962) in their study to investigate the relationship between creativity and intelligence among "gifted" children. They used the following tests:

1. Word Association

2. Uses

3. Fable

4. Make-Up-problem

5. Hidden shape.

Getzels and Jackson administered the above tests to 132 college students and obtained a composite score for the creativity measures which were then compared with intelligence test scores. From this study, the authors reported that the cream of the student crop in creativity would have been missed if traditional measures of intelligence had alone been used to reveal the "able students". It has also been indicated that it is not only the I $Q$ tests that are baised against the highly creative child but also the teachers. When they were asked to rate students on the degree to which they would prefer to have them in their classes, teachers preferred high I Q to high creativity, not withstanding the fact that the highly creative were equally superior to other students in achievement. As reported in Vernon (1980) the sample used in the Getzels and Jackson's Study was a high I.Q. one. Their main contribution to the development of creative thinking is that they have persuasively argued that it is educationally wrong to evaluate a school child purely on his intelligence test performance. This is an extension of Guilford's observation that it is intellectually wrong to conceive of intelligence in narrow terms.

The most extensive work on the application of creativity in the domain of educational practice was done by Torrance. Through his extensive work at the University of Minnesota, Torrance created measures and methods that are 
usable by teachers in the classroom setting. His aim was to provide teachers with tools they need to be able to cultivate creativity in the classroom. The Torrance tests of creative thinking is in two forms - verbal and figural - each with its alternative form $\mathrm{A}$ and $\mathrm{B}$. In one of his investigations using the tests above, Torrance (1960) observed that the creative thinking abilities contribute to acquisition of information and various educational skills.

As stated in Vernon (1980), Torrance (1960) observed that:

\footnotetext{
"traditional tests of intelligence are heavily loaded with tasks requiring cognition, memory, and convergent thinking. Such tests have worked rather well in predicting school achievement". (Torrance, 1960)
}

However, the author observed that these tests cannot successfully predict children whose mode of cognitive behaviour is creative. Using Elementary School subjects, highly creative children were separated from the highly intelligent ones. It was found that if gifted children were to be separated on the basis of scores on an intelligence tests, they would have aliminated approximately $70 \%$ of the most creative. A study of Getzels and Jackson (1962) made a similar finding.

In a study conducted by the author Suleiman (1984) using a sampe of 120 school students from two secondary schools in Sokoto State, it was found that the average intercorrelation between the measures of intelligence and creativity was 0.174 (not significant). However, the average intercorrelation within the measures of intelligence was $0.557(\mathrm{P}<0.01)$ and within the measures of creative thinking was $0.305(\mathrm{P}<.01)$.

Previous investigations such as Getzels and Jackson (1962), Torrance (1962a) and as far back as Guilford (1950) have all suggested that even though there is some positive correlation between creativity and intelligence, this is low.

It appears that there is some considerable research evidence suggesting that using intelligence tests alone as the index of intellectual giftedness is likely to penalise those children whose mode of thinking is essentially creative. We are therefore likely to be committing serious error in using tests which essentially call for productive thinking as indices of our bright or dull children. We may have children who are likely to be bright, but brightness in their own mode of thinking which is apparently not tapped by intelligence or classroom achievement tests! The label "dull child" is likely to do a serious harm to a child who could have otherwise made useful contributions to the society if only his peculiar mode of intellectual behaviour were fully tapped. It is the responsibility of our teachers and curriculum planners to make room for children who may possess cognitive giftedness that are not currently tapped by our present measures of intellectual ability. This will call for some review of our educa- 
tional policy. In his study of personality structure and experience pattern of highly creative adults, Mackinnon (1962) noted that creative students do not usually have a straight $\mathrm{A}$ in their school achievement. They can be among the B's and C's and many of them bad grades that would not admit them to graduate study. They also indicated that a creative person is a many faceted creature - original, independent, self-assertive, imaginative and sensitive. They require institutions that accommodate their values-creative learning will require creative instructions.

\section{Recommendations}

Considering the above features of a creative person, the following suggestions are put forward for out teachers and curriculum planners to encourage the development of creativity in our schools.

1. The present emphasis on reproduction of ideas needs to incorporate productive thinking as well. Teachers who pride themselves as teaching students to think and yet give exams that are almost entirely a matter of knowledge of facts are quite common in our experiences. Memorising exercises in schools does not imply thinking originally. The present notion of considering the mind of a child as an empty bottle without the ability to think productively calls for a change.

2. There is also undue demand for conformity in our classrooms. It is accepted that some reasonable degree of conformity is required. Torrance (1962) has argued that successful creative work must take place within the limits of conformity. At times conformity to accept certain values affords one the kind of licence to be constructively discontented. Benjamin (1956) also argued that it is the society which comes closest to developing every socially useful idiosyncracy in every one of its members that will make the greatest progress towards its goals.

3. The school and classroom environments should introduce a more relaxed atmosphere - that allows children to toy freely with objects. A variety of intellectual experiences and stimulation should be encouraged in the schools. Those students who make novel ideas that differ from teacher's own should be encouraged through positive reinforcement. At the moment such children are not only denied reward through praise they are even persecuted and classified as rebels and trouble makers!

If we can make teachers to present their lessons in new exciting ways and

stimulate the children and secondly make them become more aware of the 
flashes of creative responses in their students, then we may be on the road towards making our classrooms more accommodating to children of varying cognitive abilities.

\section{REFERENCES}

1. Benjamin, H. (1956) The Cultivation of Idiosyncracy Harvard University Press, Cambridge, Mass.

2. Fafunwa, A.B. (1967) History of Education in Nigeria, George Allen and Unwin Ltd., Lagos.

3. Fafunwa, A.B. (1974) New Perspectives in Ajrican Education Macmillan, Lagos.

4. Ferron, O. (1965) The Test Performance of Coloured Children, in Opara C. 1984. The Art of Questioning in the classroom. Nigerian Ed. Forum Vol. 7 (I) P. 33 - 39.

5. Getzels, J.W. \& Jackson, B.W. (19627 Creativity and Intelligence John Wiley. New York.

6. Chiselin, B. (1963a) The Creative process and its relation to the identification of creative talent. In Tayler, C.W. and Barron, F. 1963, (edits) Scientific Creativity: Its Recognition and Development. Wiley, P. 35564.

7. Guilford, J.P. (1950) Creativity, American Psychologist, 5, 444 - 454.

8. Guilford, J.P. (1967a) The Nature of Human Intelligence, McGraw Hill, New York

9. Krenter, K. \& Krenter, G. (1904) The usefur Genius Saturday Review October 17, P 64 - 67.

10. Mackinnon D.W. (1962) The personality correlates of creativity: a study of American architects; in Proceedings of the Fourteenth Congress in Applied Psychology, Vol. 2 Munksgaard, 1962.

11. Nduka O. (1975) Western Education and the Nigerian Cultural Background, Oxford University Press, Ibadan.

12. Onocha, C. \& Okpala P. (1984) Attitudes of Integrated Science Teacher Towards Assessment Practice. Nigerian Educational Forum Vol. 7 (1) P. 51 - 61.

13. Opara, C. (1984) The Arts of Questioning in the Classroom Nigerian Educational Forum Vol. 7 (1) P. 33 - 39.

14. Razik, T.A. (1967) Pyschometric Measurement of Creativity! in Money, R. and Razik, K. (eds) 1967 Explorations in Creativity. Harper and Row. New York.

15. Shapiro, R.S. (1968) Creative Research Scientist. Psychologia Africana Monograph, 4.

16. Spearman, C. (1930) Creative Mind, London, Cambridge University Press.

17. Suleiman, M. (1984) Divergent Thinking: Its relationship with Convergent Thinking and Academic Achievement of a sample of Nigerian School Students in Sokoto. Unpublished Ph.D. thesis. University of Exeter.

18. Torrance, E.P (1960) Eight Partial Replications of the Getzels Jackson Study. Bureau of Educational Research, University of Minnesota Press Minneapolis.

19. Torrance, E.P. (1962a) Education and Creative Talent, Englewood Cliffs, N.J. Prentice-Halls.

20. Torrance E. P. (1963) Education and Creative Potential, University of Minnesota Press, Minneapolis.

21. Torrance E. P. (1965) Rewarding Creative Behaviour Englewood, Cliffs. Prentice-Hall, Inc. New York.

22. Torrance, E.P. Torrance Tests of Creative Thinking: Norms-Technical Mannuals. Scholastic Testing service Inc. Bensenville. 